\title{
The Possibility of the Im-possible: Heidegger and Derrida on Responsibility
}

\section{François Raffoul}

Derrida often insists that responsibility, if it is at all, must be the experience and encounter of a certain impossible. I would like in these pages to begin exploring this claim, first through a reading of Heidegger's thought of responsibility, and then by reflecting on Derrida's aporetics of ethics. It indeed appears that for both Heidegger and Derrida, responsibility is not about a subject owning up to its actions (accountability or imputability), but rather has to do with the encounter with and exposure to an event that proves inappropriable. How such an inappropriable - which Derrida would understand in terms of what he calls the im-possible-precisely is what calls for a response, and is thus the origin of responsibility, is what I would like to show here: what I am responsible for is an impossible. I will begin by identifying three moments of inappropriability in Heidegger's thought of responsibility, before engaging Derrida's thought of the im-possible as aporetic 
site of ethics. First, a few words on the sense of responsibility in Heidegger's thought.

\section{The Inappropriability of Responsibility}

The first point that indecd we necd to bear in mind in any discussion on Heidegger and responsibility is that if there is a notion of responsibility in his work, it will not be, and it cannot be, accountability in the classical-modern, Kantiansense. Accountability, which has defined the traditional concept of responsibility, if not exhausted it, rests upon the notions of agency, free will, and subjectivity: one is accountable as a subject who is the cause of his or her actions through the freedom of the Will. Accountability, as a concept, thus assumes the position of a subject-cause, an agent or an author who can be displayed as a subjectum for its actions. Such is, for instance, Kant's definition of accountability or imputation in the first Critique (A 448/B 476). Now we know that Heidegger does not think the human being in terms of subject, and we also know that he does not think freedom in terms of free will. The basis for an identification of responsibility with accountability thus seems to disappear in the thinking of Being-which does not mean that it does not harbor another thought of responsibility.

Indeed, at the same time that the concept of accountability is deconstructed, Heidegger consistently maintains that Dasein-a being who as we know is neither a subject nor an ego, a consciousness, a person, a rational animal, or even a man-is to be thought in terms of responsibility. It in fact defines the very being of Dasein in at least three respects: responsibility defines the essence of Dasein; it constitutes selfhood; and finally, it defines humans' relationship to Being, that is, their very essence. One could go as far as to say the very concept of Dasein means 'to be a responsibility of and 
for oneself'. Heidegger says this explicitly, for instance in The Basic Problems of Phenomenology:" "Only in responsibility does the self first reveal itself" (GA 24, 194). In the 1930 Summer Semester course (GA 31, 262), on "The Essence of Human Freedom," he states that responsibility for oneself (Selbstverantwortlichkeit) represents the very essence of the human being: "Responsibility for oneself then designates the fundamental modality of being which determines all comportment of the human being, the specific and distinctive human action, ethical praxis" (GA 31, 263). This "ethical" dimension of the concept of Dasein appears early in Being and Time, in fact, as early as we are told that Dasein designates that entity for whom Being is at issue. Dasein is that entity for which and in which Being is at issue. In Jean-Luc Nancy's terms, existence is the responsibility for existence. ${ }^{2}$ Being is given in such a way that I have to take it over and be responsible for it. I am not myself as if I 'had' myself in the sense of a possession or a predicate; rather, I have being to be as my own, because such a being is addressed to me as a possible way of Being, as a way to be, and not as a "what." "To be": the being that I am is to be taken over. This determination of Dasein from the outset defines the self as a responsibility of itself. What else can the expression of Care (Sorge) mean if not that primordial responsibility of oneself that Dasein, as Zu-sein, is? For man, this is the "ultimate demand," Heidegger explains in the 1929-30 course on The Fundamental Concepts of Metaphysics: namely that he "takes upon it again, explicitly and expressly, its own Dasein and be responsible for it" (GA 29/30, 254).

We see from the outset that responsibility is not thought as a consequence of a subject "cause" of his or her actions, but is instead approached in terms of a response to an event which is also a call, the call of Being. Such a call individuates Dasein, constitutes its selfhood. Responsibility is not based on subjectness, but constitutes the self as the called one. I am 
called to be, and to make this Being my own: each time mine. ${ }^{3}$ Dasein can only be as called. Indeed, I do not posit myself like a transcendental subject, but am called to be the being that I am. Dasein has itself "announced" to itself, so to speak, by the call of existence, as having-to-be in its two senses of future and obligation. It is the call in the sense of the temporal thythm of an "each time" which individuates the I: each time, the $\mathrm{I}$ is thrown into existence, into existing; each time, Dasein is delivered over to itself. This is why the call is also that which I have to answer. There lies the hidden source and resource of responsibility: to be responsible means, before anything else, to respond, re-spondere. "Having to be oneself": such is the originary responsibility of Dasein. Heidegger also said "Become what you are," a proposition that is not to be understood ontically, as "Realize your potential!" but ontologically, that is: what you are, you can only "become it," because Dasein's being is to-be. In this "to-be" resides the ontological sense of responsibility, and it is thus a responsibility that defines the self.

The response, we should stress, does not follow the call, but is already given in the call, always already corresponding to the Saying (Zusage) of Being. In fact, Dasein cannot but answer it, it has each time already answered, already said "yes" to this call of Being, it has always-already gained access to itself in such an answer. To be responsible here means: to have been struck, always already, by this event. Heidegger writes in On the Way to Language: "[The Saying's] vow is not empty. It has in fact already struck its target-whom else but man? For man is man only because he is granted the promise of language, because he is needful to language, that he may speak it" (OWL, 90). Responsibility then refers to that event by which Being "enowns" humans. It represents human beings' very belonging to Being, as well as their essence as humans. 
Indeed, we could show that responsibility is strictly speaking not a buman responsibility but instead belongs to being itself, since, as Heidegger puts it, "in the determination of the humanity of man as ek-sistence what is essential is not man but Being" (BW, 237). Speaking of a human responsibility is still within the anthropological enclosure of the concept of responsibility: if it is the case that answerability breaks from a subject-based thinking, breaks from the autonomous subject, then how far should this break take us? I would suggest that responsibility names the co-belonging of being and Dasein (a co-belonging not posited by man but one into which man is thrown).

However, one notes that Heidegger reveals what I would call instances of inappropriability at the heart of his analytic of Dasein, which would seem to represent a veritable challenge to the very possibility of responsible agency, as they oppose the traditional values and ideals of modernity, its model of the absoluteness and transparency of subjectivity. Indeed, they challenge the very possibility of a free self-assumption of subjectivity in responsibility, since it represents precisely not only what I am not responsible for, but also what I cannot in principle appropriate. I will identify such limits-instances of the impossible-by stressing three moments: the enigma of moods; the question of birth; ontological guilt.

\section{Moods}

Whenever Heidegger describes moods in Being and Time (that is, mostly in terms of thrownness), it is in order to emphasize the element of opacity and withdrawal that seems to break and foreclose any possibility of appropriation. For example, in the paragraph devoted to 'moods' and 'affective dispositions,' which exhibit Dasein's being-thrown, Heidegger explains that moods are beyond the reach of both will and cognition. 'They are like the 'enigma,' he says, of Dasein's pure 
'that-it-is', i.e., Dasein's facticity. For instance, Heidegger states that in being-in-a-mood, "Being has become manifest as a burden." He then adds: "Why that should be, one does not know" (SZ, 135). In fact, he continues, as to this "why," Dasein "cannot know anything of the sort" (ibid., my emphasis). Cognition reaches "far too short." Now this phenomenon is not due to some weakness of our cognitive powers, which somehow could be improved; rather it has to do with the peculiar phenomenon of moods as they exhibit the facticity of Dasein. For in moods, which are a mode of disclosure, Dasein is said to be able to "burst forth as a naked 'that it is and has to be" (ibid.). Moods disclose the Being of the there in its "that it is." Heidegger states: "A mood makes manifest how one is, and how one is faring'. In this 'how one is', having a mood brings Dasein to its 'there"' (ibid). And what is peculiar with this phenomenon is that the "that it is" of our being is given in such a way that "the 'whence' and the 'wither' remain in darkness" (ibid, my emphasis). This is why cognition falls short: in the phenomenon of moods, there is this "remaining in darkness" which is irreducible: it is, Heidegger says, a "characteristic of Dasein's Being" (SZ, 135). Against this darkness, or opacity, any enlightenment is powerless, whether theoretically or practically. Moods are "beyond the range of disclosure" of both cognition and volition, beyond their possibilities of mastery. This explains, by the way, why only a "counter-mood" can master a mood, as Spinoza had already claimed. This indicates that "against the phenomenal facts of the case," all the ideals of rational enlightenment "count for nothing," "for the mood brings Dasein before the 'that-it-is' of its 'there', which, as such, stares it in the face with the inexorability of an enigma" $(S Z, 136)$. Moods thus reveal the opacity and inappropriability of our origins. In the course entitled "Introduction to Philosophy," Heidegger claims that the fact "that by its own decision Dasein has nothing to search for in the direction of its 
origin, gives an essential prod to Dasein from the darkness of its origin into the relative brightness of its potentiality-forBeing. Dasein exists always in an essential exposure to the darkness and impotence of its origin, even if only in the prevailing form of a babitual deep forgetting in the face of this essential determination of its facticity" (GA 27, 340, my emphasis).

\section{The Question of Birth}

There is therefore a dimension in our being that resists appropriation, whether practical or theoretical. That dimension is nothing other than our very coming into being, and the sheer inappropriability of it. This, of course, mobilizes the question of birth. It is often said, following Hannah Arendt, that Heidegger has neglected the phenomenon of birth, that he privileged being-towards-death. A word of caution here is necessary. Notwithstanding the fact that thrownness is the ontological name for birth (and that in the later work his reflection on phusis can be seen as pertaining to birth understood in a non-biological or naturalistic way), and that any discussion of thrownness and facticity already include a reflection on birth, we should stress that the question of birth is addressed explicitly in paragraph 72 of Being and Time. Dasein is said to exist between birth and death, not in the sense that Dasein would occupy an actual place between two external limits. Rather, Dasein exists as stretching itself between birth and death, which means: Dasein is the between of birth and death. Being that between, Dasein exists towards each of them. In other words, Dasein exists towards death, and Dasein exists towards birth. This is why Heidegger speaks of a "Being-towards-the-beginning" (Sein zum Anfang) (SZ, 373). Dasein is said to exist "towards-the-end." But there are two ends: birth and death. So principally, birth is an integral part of the existential analytic, and it is not entirely accurate to say that Heidegger ignored this dimension. Further, the charge that 
he privileged death over birth rests upon a questionable philosophical assumption, namely, first, that birth and death are somehow to be opposed as phenomena, and second that one leaves birth "behind," so to speak, to only relate to death. But Heidegger shows that in a sense birth and death should be thought as part of the same phenomenon, or that at least they are not to be opposed. And he also stresses that I am not born once in order to leave that event behind so that I now only exist towards-death; rather, the event of birth is happening each time as I exist stretching between birth and death, as being-towards birth and towards death. I am thus each time beginning, each time coming into being anew. Heidegger explains that very clearly: "Understood existentially, birth is not and never is something past in the sense of something no longer present-at-hand; and death is just as far from having the kind of Being of something still outstanding, not yet present-at-hand but coming along" (SZ, 374). As beginning, I am already dying. I exist as born, I exist as dying: the same event. I am born into death. "Factical Dasein exists as born; and as born it is already dying, in the sense of Being-towardsdeath" (ibid.). So Dasein exists as born, that is, "in a natal manner" (gebürtig existieren), which immediately means, "always already dying."

We thus exist both in a "natal" way and in a "mortal" way, in the sense that we relate to both ends, "our" ends. But are they really "ours"? In fact, they remain for Heidegger inappropriable: I can no more go back behind my coming into being than I can appropriate death by making it somehow actual. Facticity, understood as thrownness, reveals that Dasein can never go back beyond this 'throw' to recapture its being from the ground up. Dasein can never become master of and appropriate its own ground and origins. As Heidegger put it: "'Being-a-basis' means never to have power over one's ownmost Being from the ground up" (SZ, 284). I am thrown 
into existence on the basis of completely opaque (non)ground which withdraws from all attempts at appropriation. It would then seem that I am expropriated from my own being, thereby rendering any meaningful sense of responsibility impossible. And yet it seems as if responsibility happens in such a way, out of this very impossible. This, at least, is what apparent in Heidegger's analyses of being-guilty and conscience.

\section{Ontological Guilt}

Does the inappropriability of moods, birth and death indicate the radical expropriation of the human being, leading to the failure and impossibility of responsibility as the capacity to be properly one's own? We should not be too quick to come to this conclusion, for the "inappropriable" might prove to be the secret resource of appropriation, the secret resource of responsibility. In "Introduction to Philosophy," Heidegger thus explains that precisely that over which Dasein is not master must be "worked through" and "survived." He writes: "Also that which does not arise of one's own express decision, as most things for Dasein, must be in such or such a way retrievingly appropriated, even if only in the modes of putting up with or shirking something; that which for us is entirely not under the control of freedom in the narrow sense is something that is in such or such a manner taken up or rejected in the bow of Dasein (GA 27, 337, my emphasis). Finitude and facticity are not objections to existence, they are instead its very constitution, and our being-responsible, if it is at all, will have to be both factical, and finite. We should not attack existence (or the philosophers who try to think it!), in order to make it conform to a pre-set norm of accountability and subject-based thinking; we should instead drop the later in order to start thinking responsibility phenomenologically. It is therefore that sense of responsibility, i.e., as existential, finite, and factical, that needs to be brought forth. 
The inappropriable in existence as we saw in the phenomena of moods, is primarily felt as a weight or a burden. What weighs is the inappropriable. The being of the there, Heidegger writes, "become[s] manifest as a burden" (SZ, 134). But, interestingly, the very notions of weight and burden make manifest, as it were, the problematic of responsibility. In a marginal note added to this passage, Heidegger later clarified: "Burden: what one has to carry; man is charged with the responsibility (überantwortet) of Dasein, delivered over to it (übereignet)." Expropriation reveals a certain withdrawal in the gift of being: Being withdraws in the very "throw" that brings Dasein into existence. But it is this withdrawal itself that calls Dasein, which summons it to be this being-thrown as its own and be responsible for it. It is the withdrawal that calls, to be and to think, and to be "responsible" for it.

What I have to make my own is thus what can never belong to me, what evades me, what will always have escaped me. Heidegger underscored this incommensurability when he claimed that: "The self, which as such has to lay the basis for itself, can never get that basis into its power; and yet, as existing, it must take over being-a-basis" (SZ, 284, my emphasis).

Thus, what I have to appropriate, ultimately, is the inappropriable itself. I am not responsible, as Kant argued, because I am a subject as that which begins absolutely and therefore as a subject to which actions can be assigned. Rather, I am responsible because I am thrown in an existence that I have to answer for. So that to be thrown (facticity) and to be called (responsibility) are one and the same phenomenon-hence the expression "Facticity of Responsibility" (SZ, 135). Heidegger made that very point in his "Letter on Humanism." There, he explained that the phenomenon of thrownness and that of the call of being are one. For it is from the call (throw) of being that Dasein discovers itself to be thrown. He writes: Man is "called (gerufen) by being itself into the pres- 
ervation of being's truth. The call $(\mathrm{Ruf})$ comes as the throw (Wurf) from which the thrownness (Geworfenheit) of Da-sein derives" (BW, 221f). Responsibility is then brought back to its limit as to its most essential resource, if it is the case, as Heidegger puts it, that "a limit is not that at which something stops, but, as the Greeks recognized, the limit is that from which something begins its presencing" (sein Wesen beginnt) (PLT, 154 , tr. slightly modified)." The primordial sense of responsibility would hence be: the appropriation of the inappropriable, as inappropriable, having to answer a call that remains inappropriable by some willful subject-and this is what weighs. The weight, the assignation to a call that precedes me, the infinite task of owning up to it, all this indicates that ontological responsibility implies the exposure to an irreducible inappropriable otherness.

\section{Responsibility and the Im-possible: Aporetic Ethics}

This, at least, is how Derrida reads responsibility: as exposure to an incalculable alterity, an alterity that is said to be "impossible" for the subject. In a recent text, an interview for the communist newspaper l'humanité published on January 28 , 2004, Jacques Derrida stresses the following points: When he talks about ethics, he does not mean a system of rules, of moral norms, and to that extent he readily concedes that he does not propose an ethics. What interests him in ethics is instead "the aporias of ethics, its limits," what he calls the anethical origins of ethics: not to point to the simple impossibility of ethics, but on the contrary to reveal the aporia as possibility of ethics. As he puts it, it is a matter of making the impossible possible, as impossible... In a sense Derrida's thought of the impossible (which he writes as im-possible, for reasons we will explain later) is a reflection on the para- 


\section{FRANÇOIS RAFFOUL}

doxical nature of limits: both the end and secret resource. The limit (of ethics) is the aporetic site of ethics. The impossible is possible and takes place as such. In fact, it will prove to be the very structure of the event.

For instance, he rethinks the possibility of ethical decision on the basis of a "not-knowing." Already in $A$ Taste for the Secret, he maintained that "the moment of decision, and thus the moment of responsibility, supposes a rupture with knowledge, and therefore an opening to the incalculable". 4 He reiterates in the interview that the ethical moment "is independent from knowledge." When I have to decide, I do not have the knowledge of the norm by which to judge. There lies for Derrida the very opening of ethics: "It is when 'I do not know the right rule' that the ethical question arises" (C'est au moment du "je ne sais pas quelle est la bonne règle "que la question éthique se pose). This not-knowing marks the first appearance of the impossible, here identified as the an-ethical origin of the ethical, the an-ethical origin of ethics. The impossible represents a kind of inner alterity of ethics, its own resource other than it: radically depropriated as it is made possible. This is the paradox one must think. Derrida explains: "What I do is thus both an-ethical and ethical. I question the impossible as possibility of ethics" [Ce que je fais est alors aussi bien an-éthique qu'ethique. J'interroge l'impossibilité comme possibilité de l'ethique]. The same logic applies to Derrida's writings on hospitality, or forgiveness: for instance, unconditional hospitality is impossible, in the realms of politics and right, and even in ethics traditionally conceived, and yet this is what I must do. It is a matter, as the French say, of "faire l'impossible," literally "doing the impossible" (for instance, to be possible, forgiveness must forgive the unforgivable, and thus "do the impossible"). "Faire l'impossible" is the condition of ethics for Derrida. "I try to think the possibility of the impossible." 


\section{Passive Decision}

Responsible decision (a kind of "passive decision") is an openness to the incalculable. This openness is an exposure to limits that escape the calculability of the subject, being as they are the markers of the inappropriable for the subject. Responsibility is then understood as responsiveness to the opening of the incalculable, an incalculable which remains inappropriable for the subject. Derrida, as we saw, stresses that a responsible decision can never be part of a calculable horizon, that it cannot, for instance, consist in the application of a rule, a determinable rule. A leap into the incalculable is necessary for any decision to take place. A decision can only decide if the matter of the decision is not already settled. Deciding without knowing, deciding without being able to calculate all the consequences of the decision. Here lies the importance of the motif of the incalculable for Derrida's thinking of responsibility. It is a matter of marking an abyss-the leap-at the heart of responsible decision.

In order to mark such heterogeneity of responsibility to the horizon of calculability of the subject, Derrida underlies what he calls the "im-possibility" of responsibility. Here impossibility does not mean that which cannot be, but rather that which bappens outside of the conditions of possibility of the egological subject, outside of the horizons of expectation proposed by the subject, outside of transcendental horizons of calculability. "The incalculable happens." The impossible is not what simply cannot be and is thus null and void. The impossible, which Derrida writes as im-possible in order to mark the excess with respect to the horizon of the conditions of possibility of the subject, is the limit of subjectivity to which subjectivity is exposed-exposed to the establishment of the power of someone, some 'I can', "to all this I would oppose, in the first place, everything I placed earlier under the title of the im-possible, of what must remain (in a non-negative fash- 
ion) foreign to the order of my possibilities, to the order of the 'I can'." The im-possible is thus what lies outside the subject, what exceeds it, and yet happens to such a subject, happening to it as impossible. ${ }^{7}$

The impossible is also what opposes the neutralization of "the pure eventfulness of the event" (PTT, 134). In fact, an event as event is said to be im-possible in the following sense: it happens outside of the horizon of preparedness of the subject as 'I can'; it falls out of the possibilities of welcome of the subject as host. ${ }^{8}$ Derrida thus writes: "An event or an invention is possible only as im-possible." Further, this impossible event- "there is the impossible" we are told (PTT, 120)-marks the alterity of the event, absolutely. Absolutely, that is, abysmally and infinitely foreign to the 'I can': "This is what I meant earlier by heteronomy, by a law come from the other, by a responsibility and decision of the other-of the other in me, an other greater and older than I am" (PTT, 134).

An abyss thus separates the possible from the im-possible. It is for that reason that Derrida speaks of the infinite incalculability and absolute otherness of responsibility. Similarly, when speaking of hospitality as welcome of the other, Derrida shows that a conditional hospitality, one that remains regulated by the pre-existing conditions of a welcoming power, is no hospitality. Tolerance, for instance, hospitality up to a point, is not hospitality: the other is here "welcomed" on the basis of the conditions laid out by the host, that is, regulated by a welcoming power..$^{10}$ One must therefore radicalize hospitality to the point of a genuine welcome of the other, in the subjective genitive: the other arrives, in its own terms: "Whatever happens happens, whoever comes, comes" (PTT, 129); hospitality registers such an arrival. In contrast to conditional hospitality - no hospitality but exercise of power by the host over the arriving other--Derrida proposes the notion of an unconditional absolute or pure hospitality, that is, a hospitality 
not relative to the a priori conditions of the subject, and therefore absolute in that precise sense: "pure and unconditional hospitality, hospitality itself, opens or is in advance open to someone who is neither expected nor invited, to whomever arrives as an absolutely foreign visitor, as a new arrival, nonidentifiable and unforeseeable, in short wholly other (PTT, 29). Responsibility, as responsiveness to such arrival of the other, is as well incalculable, im-possible, and absolutely "of the other." Any theological turn here?

Or are we instead to understand these terms in their phenomenological senses (a phenomenology of these phenomena which exceed the horizon of finite subjectivity)? For, it is not so much a matter in Derrida's account of an hyperbolic inflation towards a theological infinite, but rather of inscribing, at the heart and limit of the immanence of experience, the transcendence of responsibility as responsiveness to the other. This transcendence happens in immanence, and does not constitute some theological beyond, because it is always the interruption and constitution of a "here," drawing its contours as it breaks it (dis-location, ex-appropriation). Derrida is quite clear on this point: "This im-possible is not privative. It is not the inaccessible, and it is not what I can indefinitely defer: it is announced to me, sweeps down upon me, precedes me, and seizes me here now, in a nonvirtualizable way, in actuality and not potentiality. This im-possible is thus not a regulative idea or ideal. It is what is most undeniably real-like the other. Like the irreducible and nonappropriable difference of the other" (PTT, 134). The other is thus not beyond, but here, in a here that is marked by trauma and difference. There is, here and now, the impossible, he writes (PT'T, 120). This sense of responsibility includes the incalculability of the open and the actual situatedness of experience as constituted/interrupted, ex-appropriated. As the passage we just cited indicates, the excess of transcendence is the advent of a here 
(situatedness) as ex-appropriation. The impossible is the very structure, and possibility, of the alterity of the event, and of responsibility as welcome of (subjective genitive) such an event.

\section{Ex-appropriation or Disaster?}

A word of caution in closing: a subject always comes to be-in responsibility-from the impossible as we described it. This is the sense of Derrida's writing of "ex-appropriation" in one word: the im-possible is possible, as im-possible. Similarly, we saw how in Heidegger the inappropriability of birth and death constituted the very advent of a finite self and even the possibility of responsibility. And yet, could one not object to this expropriated appropriation or ex-appropriation-or perhaps better to this appropriated expropriationanother sense of the impossible, the one that Maurice Blanchot designated as "disaster"?"11 Blanchot speaks of the disaster of the impossibility of undergoing an experience in the sense of a subject being able to synthesize, to make-present, to work through and appropriate, a kind of passivity as exile from experience. In the experience of suffering, there is no " $\mathrm{I}$ " that suffers: it is the place where the "I" ends. There lies what Derrida also called the radical impossibility of mourning, of working through, thus of appropriation and perhaps also of ex-appropriation. The disaster is the radical loss of the prospect of salvation. The experience of the impossibility of experience is disaster. Experience is the experience of limits, of what therefore remains inappropriable or "impossible" for the subject (in the sense of what I cannot do, or be). Would a subject "in disaster" not mark the end of ex-appropriation, its radical disappearance, its eventual impossibility? 


\section{'I'HE POSSIBILI'I'Y OF' I'HE IM-POSSIBLE}

\section{Notes}

${ }^{1}$ Texts by Heidegger will be cited in the body of the text as follows:

BW: Basic Writings (New York: Harper \& Row, 1977).

GA 24 Die Grundprobleme der Phänomenologie (Frankfurt am Main: Vittorio Klostermann, 1975). English translation: The Basic Problems of Phenomenology. Trans. Albert Hofstadter (Bloomington: Indiana University Press, 1982).

GA 27 Einleitung in die Philosophie, Ed. Otto Saame and Ina Saame-Speidel (Frankfurt am Main: Vittorio Klostermann, 1996).

GA 29/30 Die Grundbegriffe der Metapbysik (Frankfurt am Main: Vittorio Klostermann, 1983). English translation: Fundamental Concepts of Metaphysics. Trans, W. McNeill and N. Walker (Bloomington: Indiana University Press, 1995).

GA 31 Vom Wesen der menschlichen Freiheit (Frankfurt am Main: Vittorio Klostermann, 1982).

OWL On the Way to Language. Trans. Peter D. Hertz (New York: Harper \& Row, 1971).

PLT Poetry, Language, Thought. Trans, Albert Hofstadter (New York: Harper \& Row 1971).

SZ Sein und Zeit, 9th ed. (Tübingen: Max Niemeyer, 1960). English translation: Being and Time. Trans. John Macquarrie \& Edward Robinson (New York: Harper \& Row, 1962).

${ }^{2}$ On this point, see "Responding to Existence," in A Finite Thinking (Stanford: Stanford University Press, 2003).

${ }^{3}$ On this "each time mine," see my $A$ Chaque Fois Mien (Paris: Galilée, 1994).

${ }^{4}$ A Taste for the Secret (Malden, MA: Polity Press, 2001), 61.

${ }^{5}$ Ibid.

${ }^{6}$ Philosopby in a Time of Terror. Dialogues with J. Habermas and Jacques Derrida. Ed. Giovanna Borradori (Chicago: University of Chicago Press, 2003), 134. Hereafter abbreviated in the text as PT"T.

${ }^{7}$ In $A$ Taste for the Secret, Derrida speaks of the absolute weakness and disarmament which allows the incalculable to happen; he speaks of the event of "the occasion, chance, the aleatory", which means "exposing ourselves to what we cannot appropriate: it is there, before us, without us --there is someone, something, that happens, that happens to us, and that has no need of us to happen (to us)," 63. 


\section{FRANÇOIS RAFFOUL}

${ }^{8}$ On this, see my "The Subject of the Welcome," in Symposium (Fall 1998).

'Jacques Derrida. "The 'World' of the Enlightenment to Come," in Research in Phenomenology (Leiden: Brill Academic Publishers, 2003), volume 33, p.35.

${ }^{10}$ On Derrida's reservations with respect to the notion of tolerance, its dogmatism and relativism, see The Taste for the Secret, 62-64.

${ }^{11}$ Maurice Blanchot. The Writing of the Disaster. Trans. Ann Smock (Lincoln and London: University of Nebraska Press, 1986). 